\title{
PENILAIAN KERENTANAN HABITAT MANGROVE di KELURAHAN MANGUNHARJO, KECAMATAN TUGU, KOTA SEMARANG TERHADAP VARIABEL OSEANOGRAFI BERDASARKAN METODE CVI (COASTAL VULNERABILITY INDEX)
}

\author{
Agus Wahyudi, Boedi Hendrarto ${ }^{\text {, Agus Hartoko }}$
}

Program Studi Manajemen Sumberdaya Perairan, Jurusan Perikanan Fakultas Perikanan dan Ilmu Kelautan, Universitas Diponegoro

\begin{abstract}
ABSTRAK
Mangrove merupakan tumbuhan atau vegetasi pantai tropis yang hidup di wilayah pesisir yang luas dan terbuka. Hutan mangrove disebut juga sabuk hijau karena mangrove berfungsi sebagai pelindung pantai dari hantaman gelombang laut. Habitat mangrove memiliki beberapa sifat atau karakteristik yang khusus diantaranya salinitas, pasang surut, angin, dan substrat yang berlumpur. Kerentanan variabel oseanografi di habitat mangrove dan pembukaan lahan kawasan hutan mangrove menjadi lahan tambak budidaya dan lahan industri menyebabkan kondisi hutan mangrove di Kota Semarang mengalami degradasi atau penurun kondisi habitat mangrove, oleh karena itu perlu dilakukan kajian mengenai seberapa besar kerentanan dari karakteristik habitat mangrove yang mempengaruhi kerentanan habitat mangrove di pesisir Kota Semarang sehingga diketahui tingkat kerentanan di daerah habitat mangrove. Tujuan dari penelitian ini adalah mendapatkan nilai indeks kerentanan habitat mangrove dan mengetahui kondisi kerentanan habitat mangrove di lokasi penelitian berdasarkan variabel salinitas, jenis substrat, dan pasang surut. Penelitian ini menggunakan metode survey dan metode eksploratif sedangkan untuk pengamatan objek menggunakan metode purposive dan perhitungan nilai indeks kerentanan habitat mangrove menggunakan metode CVI (Coastal Vulnerability Index). Hasil penelitian menunjukkan bahwa kerentanan habitat mangrove berdasarkan data pasang surut termasuk dalam kategori kerentanan tinggi dan kerentanan habitat mangrove berdasarkan variabel nilai salinitas termasuk dalam kategori kerentanan rendah, sedangkan untuk kerentanan habitat mangrove berdasarkan variabel jenis substrat termasuk dalam kategori kerentanan sedang. Nilai CVI habitat mangrove yang didapatkan berdasarkan perhitungan yaitu 2.12 , hal itu menunjukkan kerentanan habitat mangrove di lokasi penelitian masuk dalam kategori kerentanan rendah.
\end{abstract}

Kata Kunci: Mangrove, Habitat Mangrove, Kerentanan Pesisir, CVI.

\section{ABSTRACT}

Mangrove is plant or vegetation of tropical beach that living in coastal areas which vast and open. Mangroves forest also called green belt because mangrove serves as a protective shore from sea waves. Mangrove habitat has some special characteristics such salinity, tides, winds, and muddy substrates. Vulnerability oceanografi variabel of mangrove habitat and changing of mangrove forests into aquaculture ponds and industrial land cause condition in the mangrove forest in Semarang degraded of mangrove habitat conditions. Therefore it necessary to study about the importance the vulnerability of mangrove habitat characteristics that affect the vulnerability of mangrove habitat in the coastal of Semarang with the result that to known the vulnerability of mangrove habitat. The purpose of this research was to get the value of mangrove habitat vulnerability index and determine the vulnerability of mangrove habitat conditions at the study site based on variable salinity, substrate type, and tides. This research used survey and exploratory methods and for the observation of objects using purposive sampling method and the calculation of the value of mangrove habitat vulnerability index using CVI method (Coastal Vulnerability Index). The results showed that the vulnerability of mangrove habitat based on tidal data included in the category of high vulnerability and vulnerability index of mangrove habitats by salinity included in the category of low vulnerability, whereas for the vulnerability of mangrove habitat based on the type of substrate included in the category of medium vulnerability. CVI value of mangrove habitat obtained by calculation was 2.12 . The total vulnerability index of mangrove habitat at the research area included in the category of low vulnerability.

Keywords: Mangrove, Habitat of Mangrove, Coastal Vulnerability, CVI.

1) Penulispenanggung Jawab 


\section{Pendahuluan}

Mangrove merupakan tumbuhan atau vegetasi pantai tropis yang hidup di wilayah pesisir yang luas dan terbuka. Mangrove banyak ditemukan terutama di daerah beriklim tropis. Mangrove berfungsi sebagai menjaga garis, mengurangi energi angin, dan sebagai habitat atau tempat hidup bagi biota - biota lainnya seperti ikan, udang, moluska, dan kepiting.

Banyak faktor yang mempengaruhi keberlangsungan hidup dan pertumbuhan mangrove diantaranya mangrove biasanya tumbuh dengan baik di habitat yang lembab dan berlumpur serta dipengaruhi oleh pasang surut. Habitat mangrove memiliki beberapa sifat atau karakteristik yang khusus diantaranya salinitas, pasang surut, angin, dan substrat yang berlumpur. Faktor - faktor tersebut membantu mangrove dalam pertumbuhan dan keberlangsungan hidup mangrove. Mangrove biasanya tumbuh dengan baik pada substrat tanah atau pasir dengan tekstur halus seperti lumpur dan kaya humus dan sulfida (Kathiresan dan Thangam, 1990).

Kerusakan hutan mangrove di Kota Semarang diawali dengan adanya booming budidaya udang pada tahun 1980 - 1990. Masyarakat diberi modal untuk menguasai kawasan hutan mangrove secara ilegal dan membukanya untuk tambak udang, sedangkan kerusakan hutan mangrove di pesisir jawa bagian utara diakibatkan oleh alih fungi lahan untuk industri. Hingga tahun 2009, garis pantai di pesisir Jawa Tengah sepanjang 690,95 kilometer telah mengalami abrasi seluas 5.600 hektar (16\%). Angka ini belum termasuk kerusakan terumbu karang sekitar 4.000 hektar dan lahan bekas galian tambang sekitar 400 hektar. Berbagai upaya penghijauan garis pantai telah banyak dilakukan oleh pemerintah dan masyarakat sejak tahun 1990 an. Namun hal ini belum dapat mengatasi bencana yang terjadi akibat hilangnya hutan mangrove, seperti banjir rob, abrasi, penurunan lahan dan intrusi air laut. Pada tahun 2012 luasan hutan mangrove di Kota Semarang berkisar 1.934.730 HA (Kementrian Kehutanan, 2012).

Perubahan iklim yang berpengaruh terhadap variabel oseanografi habitat mangrove sehingga berpotensi menjadi faktor yang mempengaruhi kestabilan hutan mangrove di Kota Semarang, sehingga perlu dilakukan kajian kerentanan wilayah pesisir dengan objek kajian habitat mangrove dengan menggunakan metode kerentanan wilayah pesisir atau disebut juga metode CVI (Coastal Vulnerability Index) untuk mengetahui kondisi kerentanan habitat mangrove.

CVI (Coastal Vulnerability Index) merupakan salah satu metode yang telah dikembangkan untuk penilaian kerentanan wilayah pesisir yang diakibatkan oleh perubahan iklim. Menurut Ramieri et al, (2011), CVI merupakan metode yang berbasis indeks dan telah umum digunakan dalam menilai kerentanan pesisir terhadap dampak kenaikan muka air laut, terutama terkait dampak akibat oleh adanya erosi dan limpahan (inundation).

Secara umum metode CVI menerapkan metode pendekatan yang sederhana dalam penyediaan data perankingan variabel-variabel dari garis pantai (coastal section) dalam hal ini objek kajian berupa habitat mangrove sehingga dari penelitian ini dapat mengetahui tingkat kerentanan di daerah habitat mangrove pada lokasi penelitian.

\section{Metode Penelitian}

Penelitian ini menggunakan metode CVI (Coastal Vulnerability Index). CVI adalah metode yang dikembangkan oleh Gornitz, 1990 yang digunakan untuk menilai berapa besar pengaruh dari kenaikan tinggi permukaan air laut terhadap kondisi wilayah pesisir di Amerika.

Meode CVI menggunakan beberapa data yang digunakan sebagai variabel penunujang untuk mengukur kondisi kerentanan suatu wilayah pesisir. Penelitian ini menggunakan objek habitat mangrove yang akan diteliti tingkat kerentanannya dengan menggunakan variabel - variabel oseanografi yang digunakan sebagai data penunjang untuk mengukur tingkat kerentanan di wilayah habitat mangrove.

\section{Variabel Indeks Kerentanan Habitat Mangrove}

Variabel yang digunakan dalam analisis Indeks Kerentanan Habitat Mangrove meliputi empat variabel yang terdiri dari data primer yaitu data yang daimbil langsung di lapangan atau in - situ meliputi data salinitas dan jenis substrat sedangkan data sekunder yaitu data pasang surut Kota Semarang tahun 2013 yang didapatkan dari BBPPI (Balai Besar Pengembangan Penangkapan Ikan) Kota Semarang tahun 2013, kemudian diolah untuk mendapatkan lama waktu penggenangan pasang surut dan tinggi $(h)$ genangan maksimum air pasang.

\section{Pengukuran Data Variabel Indeks Kerentanan Habitat Mangrove}

1. Salinitas

Pengukuran salinitas pada lokasi penelitian dilakukan pada 20 titik yang tersebar di lokasi penelitan. Penentuan titik didasarkan kepada daerah - daerah yang dianggap mewakili lokasi penelitaan. Pengukuran salinitas menggunakan refraktometer dengan menggunakan air laut sebagai sampel airnya. Pengukuran indeks kerentanan habitat mangrove variabel salinitas dilakukan dengan metode purposive sampling yaitu pengukuran variabel yang dilakukan di lokasi-lokasi sampling berdasarkan daerah keterwakilan objek yang akan dikaji sehingga hasil yang didapatkan dapat mewakili dari daerah - daerah objek habitat mangrove yang dikaji. 


\section{Jenis Substrat}

Pengukuran variabel jenis substrat dilakukan dengan pengambilan sampel uji pada delapan titik di lokasi penelitian yang tersebar pada daerah penelitian dan dianggap mewakili lokasi penelitian. Metode pengambilan sampel substrat dilakukan dengan metode purposive sampling dan cara pengambilan sampel langsung di lokasi penelitian untuk selanjutnya delapan sampel substrat yang telah didapat akan dilakukan uji grand size analysis di Laboratorium Manajemen Sumberdaya Perairan, Jurusan Perikanan, Universitas Diponegoro, sehingga didapatkan kadar kandungan jenis substrat yang mendominasi di lokasi penelitian.

3. Lama Waktu Genangan Pasang Surut

Variabel lama waktu genangan didapatkan dengan cara pengolahan data sekunder yaitu data pasang surut Kota Semarang pada tahun 2013 yang didaptakan dari BBPPI (Balai Besar Pengembangan Penangkapan Ikan) Kota Semarang yang selanjutnya diolah dengan menggunakan bantuan Software Matlab 7.6 untuk mendapatkan nilai konstanta harmonik yang kemudian dilakukan perhitungan dari konstanta harmonik tersebut untuk mendapatkan nilai Formhzl ( F ). Nilai F digunakan untuk mengetahui tipe pasang surut yang ada di kota Semarang yang kemudian akan menjadi acuan tipe pasang surut Kota Semarang setia bulannya pada tahun 2013. Nilai F didapatkan dari perhitungan dengan menggunakan perhitungan konstanta harmonik dengan menggunakan rumus (Foreman, 2004).

Jika bilangan Formzahl (F) yang diperoleh adalah:

$$
\mathrm{F}=\frac{K 1+O 1}{M 2+S 2}
$$

0,25 : tipe pasang surut harian ganda

$0,26-1,50$ : tipe pasang surut campuran condong ke harian ganda

$1,50-3,00:$ tipe pasang surut campuran condong ke harian tunggal

$>3,00 \quad$ : tipe pasang surut harian tunggal

4. Tinggi $(h)$ Genangan Pasang Maksimum

Variabel tinggi $(h)$ genangan maksimum didapatkan dengan melakukan perhitungan ketinggian maksimum air pasang Kota Semarang yang didapatkan dari data pasang surut Kota Semarang. Perhitungan tinggi genangan maksimum air saat pasang dilakukan dengan cara melakukan perhitungan rata - rata tinggi maksimum air pasang pada setiap bulan pada tahun 2013 sehingga didapatkan nilai tinggi $(h)$ genangan maksimum pada lokasi penelitian.

\section{Pengolahan Data Citra}

Proses pengolahan data citra dilakukan dengan menggunakan software ER Mapper 7.0 dan pengolahannya disesuaikan dengan kebutuhan informasi yang dibutuhkan dalam penelitian, sehingga pola distribusi mangrove dan daerah sebaran ROB dapat diketahui dengan baik. Tahapan-tahapan proses pengolahan data citra adalah sebagai berikut:

1. Koreksi Geometrik

Koreksi geometrik adalah memberikan input dan koordinat pada data citra awal yang belum memiliki koordinat (Hartoko dan Helmi, 2008). Koreksi geometrik bertujuan untuk mengkonversi bentuk muka bumi yang terekam oleh satelit (tidak datar) ke bidang datar dengan penempatan garis lintang dan garis bujur sesuai dengan titik koordinatnya.

2. Koreksi Radiometrik

Koreksi radiometrik bertujuan untuk meminimalkan pembiasan data yang ditangkap oleh satelit karena diakibatkan faktor-faktor penganggu di atmosfer seperti awan.

3. Citra Komposit Warna

Citra komposit warna adalah kombinasi band yang terpakai dalam pemprosesan data citra dengan pemilihan kombinasinya disesuaikan dengan objek yang akan diteliti. Citra komposit warna bertujuan untuk memperjelas sebaran data yang dibutuhkan dalam bentuk warna yang mencolok, sehingga didapatakan dengan jelas objek yang menjadi fokus utama penelitian (Hartoko, 2002).

4. Cropping Data Citra

Cropping atau pemotongan data citra dilakukan untuk membatasi daerah atau lokasi penelitan sehingga data citra yang tersedia terpusat pada daerah atau objek yang dikaji. Cropping data citra juga untuk mempermudah peneliti dalam mencari daerah atau wilayah penelitan yang ada pada data citra satelit.

5. Pemprosesan Akhir Data Citra

Pemprosesan akhir data citra ini bertujuan untuk mendapatkan hasil akhir berupa peta indeks kerentanan habitat mangrove Kota Semarang lengkap dengan skala, legenda dan keterangan sehingga memudahkan bagi para pembaca untuk mengerti dan memahami isi dan maksud dari peta indeks kerentanan habitat mangrove di Kota Semarang. 


\section{Analisis CVI}

Penilaian kerentanan dalam metode CVI memiliki konsep sederhana. Potensi kerentanan (ranking) tiap variabel dinilai berdasarkan kisaran nilainya masing-masing menurut sistem ranking yang ditetapkan oleh USGS (USGS, 1999). Nilai variabel terdiri atas 5 kelas (1= sangat rendah, $2=$ rendah, $3=$ moderat, $4=$ tinggi, $5=$ sangat tinggi), tetapi dalam penelitian ini hanya menggunakan 3 kelas yaitu kelas $1=$ rendah, kelas $2=$ sedang, kelas 3 = tinggi selanjutnya potensi kerentanan simultan (indeks kerentanan) dinilai berdasarkan hasil perhitungan masing-masing nilai tiap variabel melalui persamaan, sebagai berikut:

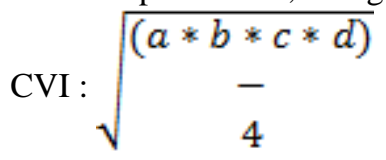

di mana; $C V I=$ nilai (skor) Indeks Keretanan Habitat Mangrove, $a=$ nilai variabel frekuensi lama pasang surut, $b=$ nilai variabel tinggi genangan pasang surut maksimum, $c=$ nilai variabel nilai salinitas, $d=$ nilai variabel jenis substrat. Berdasarkan nilai skor dari persamaan maka distribusi kategori kerentanan (indeks) di sepanjang habitat mangrove yang didominasi oleh jenis Rhizopora dan Avicennia yang dinilai menggunakan aturan Boruff, 2005 yang telah dimodifikasi. Melalui pendekatan ini indeks kerentanan mangrove dikelompokkan menurut nilainya masing-masing terhadap kelas kategori yang telah ditentukan sebelumnya. Berdasarkan aturan tersebut maka kategori indeks kerentanan habitat mangrove berdasarkan nilai CVI-nya dibedakan atas skor; rendah (0.45-4.02), sedang (4.03-8.04), tinggi (8.05-12.07).

Variabel yang digunakan dalam menentukan Coastal Vulnerability Index pada habitat mangrove menggunakan empat variabel dengan pemobotan kerentanan habitat mangrove secara rinci disajikan pada tabel 1 .

Tabel 1. Kategori Penilaian Coastal Vulnerability Index Habitat Mangrove.

\begin{tabular}{cccc}
\hline Variabel & Rendah $=\mathbf{1}$ & Sedang $=\mathbf{2}$ & Tinggi $=\mathbf{3}$ \\
\cline { 2 - 4 } & $10-19$ & 20 & $<10$ atau $>20$ \\
\hline $\begin{array}{c}\text { Lama Waktu Genangan } \\
\text { Pasang surut (Bulan) } \\
\text { (Chapman, 1976) }\end{array}$ & & & $>1$ \\
\hline $\begin{array}{c}\text { Tinggi genangan pasang } \\
\text { surut maksimum (m) } \\
\text { (Giesen } \text { et al, 2006) }\end{array}$ & $<0,5$ & $0,5-1$ & \\
\hline $\begin{array}{c}\text { Salinitas (Kathiresan dan } \\
\text { Thangam, 1990) }\end{array}$ & $15-30 \% 00$ & $10-15 \% ;$ & \\
\hline $\begin{array}{c}\text { Substrat } \text { stal, 2006) } \\
\text { (Giesen } \text { et al, }\end{array}$ & Lumpur & Pasir & Batu \\
\hline
\end{tabular}

\section{Hasil dan Pembahasan}

A. Hasil

\section{Kondisi Umum Lokasi Penelitian}

Kawasan habitat mangrove yang menjadi objek penelitian berada di mangkang, kelurahan Mangunharjo, Kecamatan Tugu, Kota Semarang. Kawasan ini merupakan daerah yang sering terkena dampak ROB ketika air laut pasang yang tinggi serta daerah ini mengalami kerusakan garis pantai yang parah diakibatkan abrasi yang terus menerus sepanjang tahun.

Menurut Dinas Kelautan dan Perikanan Jawa Tengah (2012), luas area hutan mangrove Kota Semarang mencapai 94,39 ha atau 3.84\% dari total luasan area mangrove di Jawa Tengah dengan 46,19 ha berada di Kelurahan Mangunharjo, Kecamatan Tugu. Spesies mangrove yang ditemukan di Kota Semarang khususnya di Kelurahan Mangunharjo, ditemukan dua spesies mangrove yang bersifat mayor atau mendominasi yaitu Rhizophora mucronata dan Avicennia marina dengan nilai diameter batang pohon berkisar $4 \mathrm{~cm}-16 \mathrm{~cm}$ dan tinggi pohon berkisar $1 \mathrm{~m}-5 \mathrm{~m}$.

\section{Pasang Surut}

Pengolahan data pasang surut dilakukan pada setiap data dari data bulanan pada tahun 2013. Data bulanan tersebut dilakukan perhitungan untuk mendapatkan nilai Formzahl (F). Nilai F merupakan nilai konstanta harmonik dari data pasang surut di Kota Semarang, dari nilai F dapat diketahui tipe pasang surut Kota Semarang yang telah diolah dalam setiap bulannya sehingga untuk selanjutnya nilai $F$ tersebut dapat menentukan tipe pasang surut yang terjadi pada bulan tersebut.

Berdasarkan pengolahan data pasang surut yang dilakukan dengan bantuan Software Matlab maka didapatkan tipe pasang surut Kota Semarang termasuk ke dalam tipe pasang surut campuran condong ke harian tunggal yang artinya adalah peristiwa pasang surut di Kota Semarang dalam satu hari terjadi satu kali air pasang dan satu kali air surut, tetapi kadang-kadang untuk sementara waktu peristiwa pasang surut dapat 
http://ejournal-sl.undip.ac.id/index.php/maquares

juga terjadi dua kali pasang dan dua kali surut dengan tinggi dan periode yang sangat berbeda. Tipe pasang surut Kota Semarang dapat dilihat pada Tabel 2.

Tabel 2. Nilai F dan Tipe Pasang Surut Kota Semarang

\begin{tabular}{cclc}
\hline Bulan & Nilai F & Tipe Pasang Surut & Bobot \\
\hline Januari & 1,8 & Campuran condong ke harian tunggal & 3 \\
Februari & 1,87 & Campuran condong ke harian tunggal & 3 \\
Maret & 1,82 & Campuran condong ke harian tunggal & 3 \\
April & 1,65 & Campuran condong ke harian tunggal & 3 \\
Mei & 1,65 & Campuran condong ke harian tunggal & 3 \\
Juni & 1,79 & Campuran condong ke harian tunggal & 3 \\
Juli & 1,76 & Campuran condong ke harian tunggal & 3 \\
Agustus & 1,65 & Campuran condong ke harian tunggal & 3 \\
September & 1,67 & Campuran condong ke harian tunggal & 3 \\
Oktober & 1,76 & Campuran condong ke harian tunggal & 3 \\
November & 1,62 & Campuran condong ke harian tunggal & 3 \\
Desember & 1,61 & Campuran condong ke harian tunggal & 3 \\
\hline
\end{tabular}

Sumber: (Hasil Penelitian, 2013)

Tipe pasang surut campuran condong ke harian tunggal dalam indeks kerentanan habitat mangrove termasuk kedalam kategori kerentanan tinggi karena pasang surut pada lokasi penelitan terjadi selama 30 hari/bulan - 31 hari/bulan atau setiap hari mangrove di lokasi penelitian tergenang saat terjadi pasang, sehingga nilai bobot pada variabel tipe pasang surut adalah tiga. Pemetaan nilai bobot untuk variabel lama waktu penggenangan pasang surut dapat dilihat pada Gambar 1 .

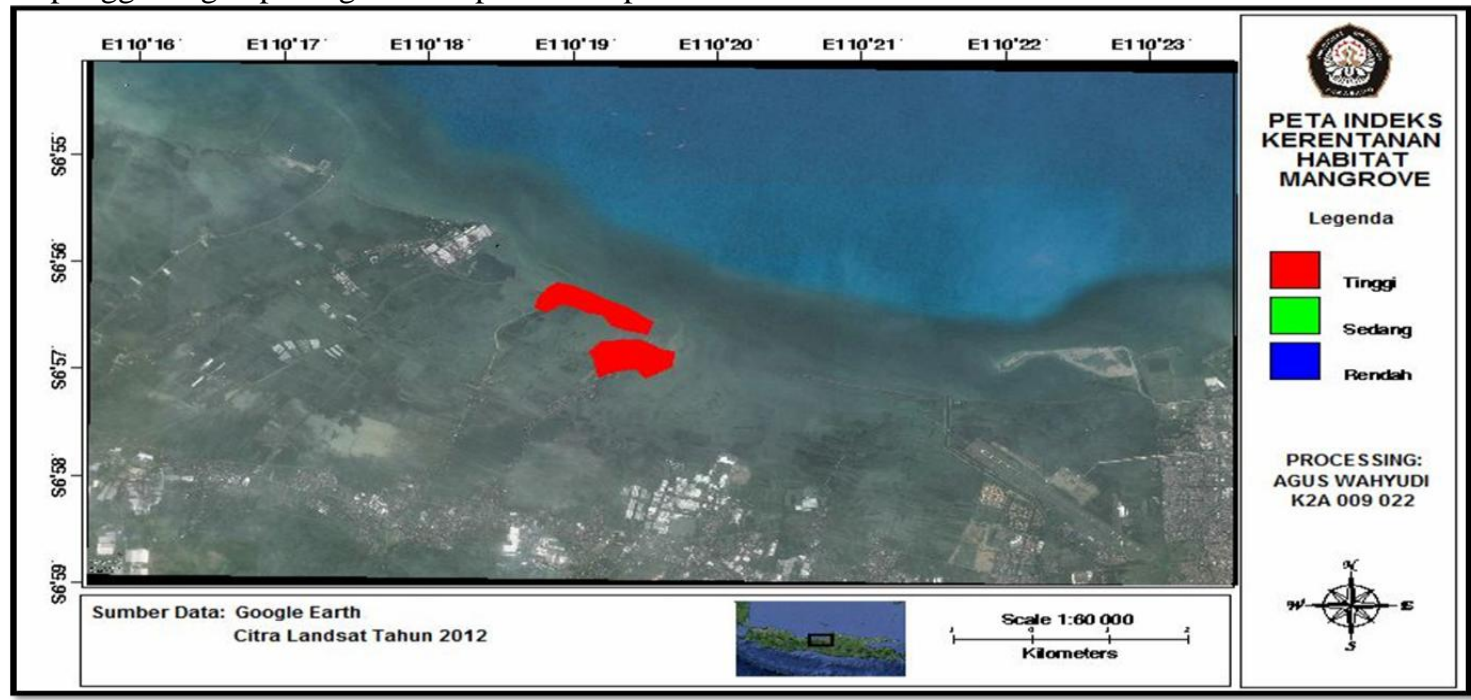

Gambar 1. Peta Indeks Kerentanan Habitat Mangrove Berdasarkan Variabel Lama Waktu Genangan Pasang Surut

Tinggi genangan maksimum pasang surut Kota Semarang pada tahun 2013 yaitu 1,075 m. Data tersebut didapatkan setelah melakukan perhitungan tinggi rata - rata air pasang di Kota Semarang pada setiap bulannya pada tahun 2013. Ketinggian maksimum air pasang di Kota Semarang dapat dilihat pada Tabel 3.

Tabel 3. Ketinggian Maksimum Air Pasang Kota Semarang

\begin{tabular}{ccc}
\hline Bulan & Tinggi $(\mathrm{m})$ & Bobot \\
\hline Januari & 1 & 3 \\
Februari & 1 & 3 \\
Maret & 1.1 & 3 \\
April & 1.1 & 3 \\
Mei & 1.1 & 3 \\
Juni & 1.1 & 3 \\
Juli & 1 & 3 \\
Agustus & 1.1 & 3 \\
September & 1.1 & 3 \\
Oktober & 1.1 & 3 \\
November & 1.1 & 3 \\
Desember & 1.1 & 3 \\
\hline Rata - Rata & 1.075 & 3
\end{tabular}

Sumber: (Hasil Penelitian, 2013) 


\section{http://ejournal-s1.undip.ac.id/index.php/maquares}

Tinggi genangan pasat surut yang mencapai 1,075 $\mathrm{m}$ dalam indeks kerentanan habitat mangrove termasuk dalam kategori kerentanan tinggi. sehingga nilai bobot pada variabel tinggi genangan maksimum adalah tiga. Pemetaan nilai bobot untuk variabel tinggi genangan maksimum dapat dilihat pada Gambar 2.

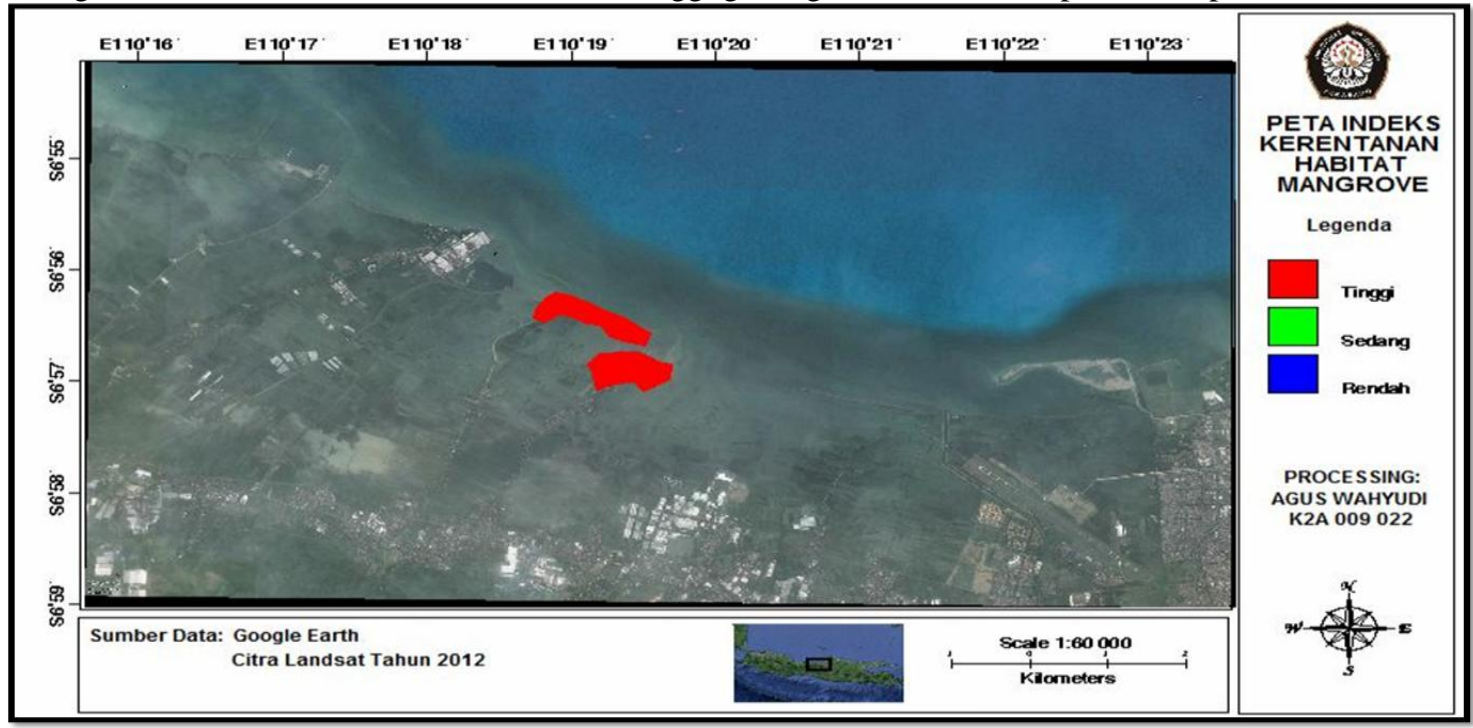

Gambar 2. Peta Indeks Kerentanan Habitat Mangrove Berdasarkan Variabel Tinggi Genangan Maksimum Salinitas

Salinitas merupakan salah satu variabel yang mempengaruhi kondisi baik buruknya suatu habitat mangrove. Banyak faktor yang mempengaruhi nilai salinitas di suatu wilayah perairan. Faktor - faktor yang mempengaruhi nilai salinitas di suatu wilayah perairan antar lain seperti ketebukaan lahan atau wilayah tersebut, luas area, dan aktivitas pasang surut serta pengaruh dari adanya intrusi air laut di wilyah tersebut.

Hasil pengukuran nilai salinitas di lapangan menunjukkan bahwa kisaran nilai salinitas yang didapatkan di lokasi penelitian tidak menghasilkan perbedaan yang tinggi. Nilai salinitas yang didapatkan pada pengukuran langsung di lokasi penelitian berkisar antara $29 \%$ - $30 \%$ untuk setiap titik pengamatan.

Hasil pengukuran nilai salinitas dari 20 titik pengamatan yang menggunakan alat refraktometer didapatkan kisaran nilai salinitas antara $29 \%-30 \%$ sehingga nilai salinitas di lokasi penelitian dalam indeks kerentanan habitat mangrove termasuk dalam kategori kerentanan rendah karena termasuk dalam kisaran $29 \%$ - 33\% $\%_{00}$. Nilai bobot pada variabel salinitas adalah satu. Pemetaan nilai bobot untuk variabel salintas dapat dilihat pada Gambar 3.

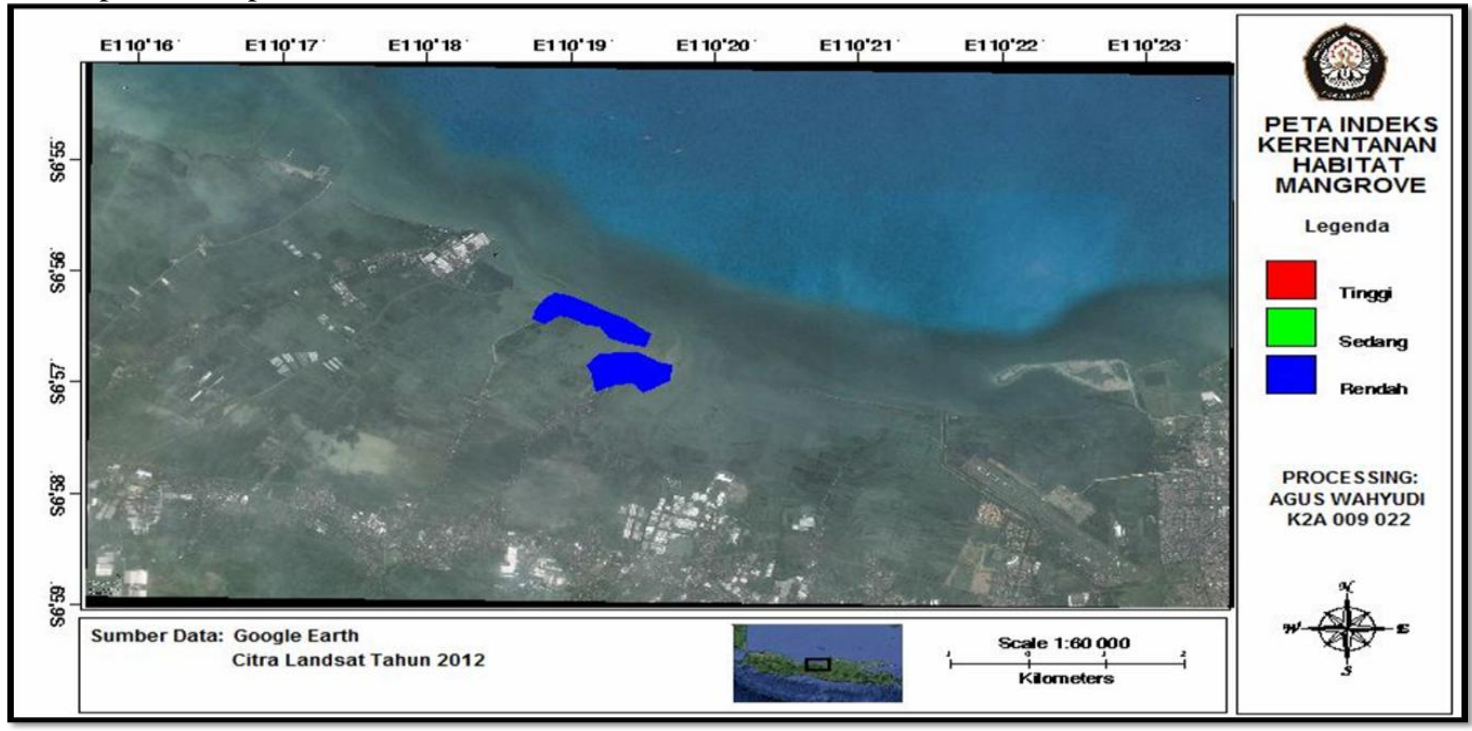

Gambar 3. Peta Indeks Kerentanan Habitat Mangrove Berdasarkan Variabel Nilai Salinitas

\section{Substrat}

Pengamatan untuk jenis substrat yang ada di lokasi penelitian dilakukan dengan melakukan uji analisis kandungan substrat pada habitat mangrove melalui grand size analysis yang dilakukan di Laboratorium Manajemen Sumberdaya Perairan, Jurusan Perikanan, Universitas Diponegoro. Hasil yang didapatkan setelah dilakukan grand size analysis tersaji pada Tabel 4. 
http://ejournal-s1.undip.ac.id/index.php/maquares

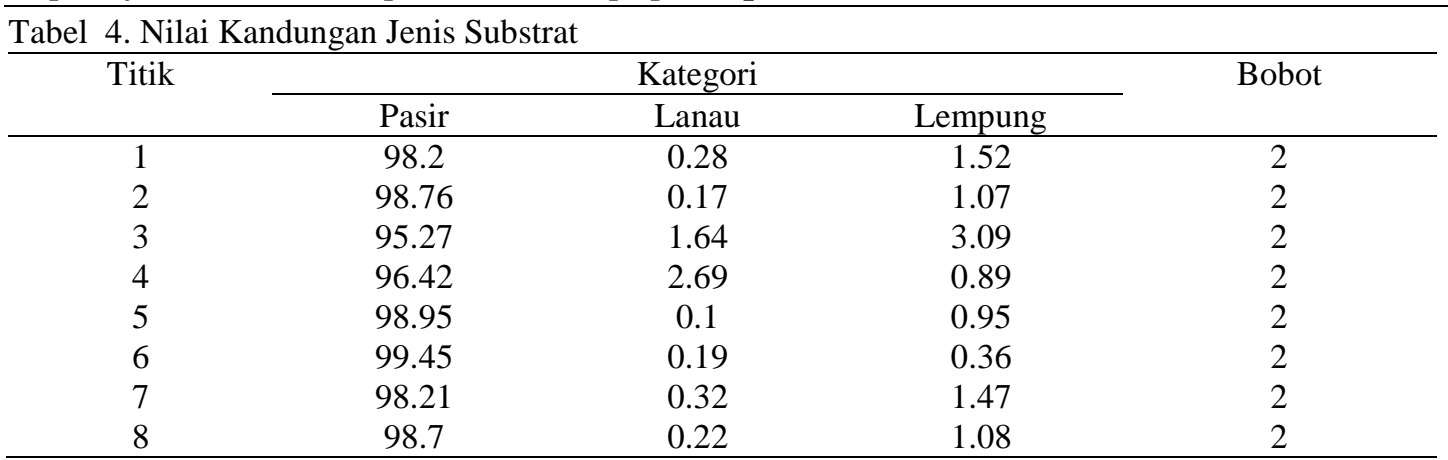

Sumber: (Hasil Penelitian, 2013)

Jenis substrat yang didapatkan di lokasi penelitian dari hasil uji laboratorium didapatkan pada delapan sampel uji memiliki kandungan pasir yang lebih banyak daripada lanau dan lempung. Hal ini bisa dilihat dengan komposisi substrat $90 \%$ lebih di dominasi oleh pasir dan sisanya adalah lanau dan lempung.

Jenis subsrat pada lokasi penelitian merupakan kategori pasir berlanau sehingga dalam Coastal Vulnerability Index termasuk dalam kategori kerentanan sedang, sehingga nilai bobot pada variabel jenis substrat adalah tiga. Pemetaan nilai bobot untuk variabel jenis substrat dapat dilihat pada Gambar 4.

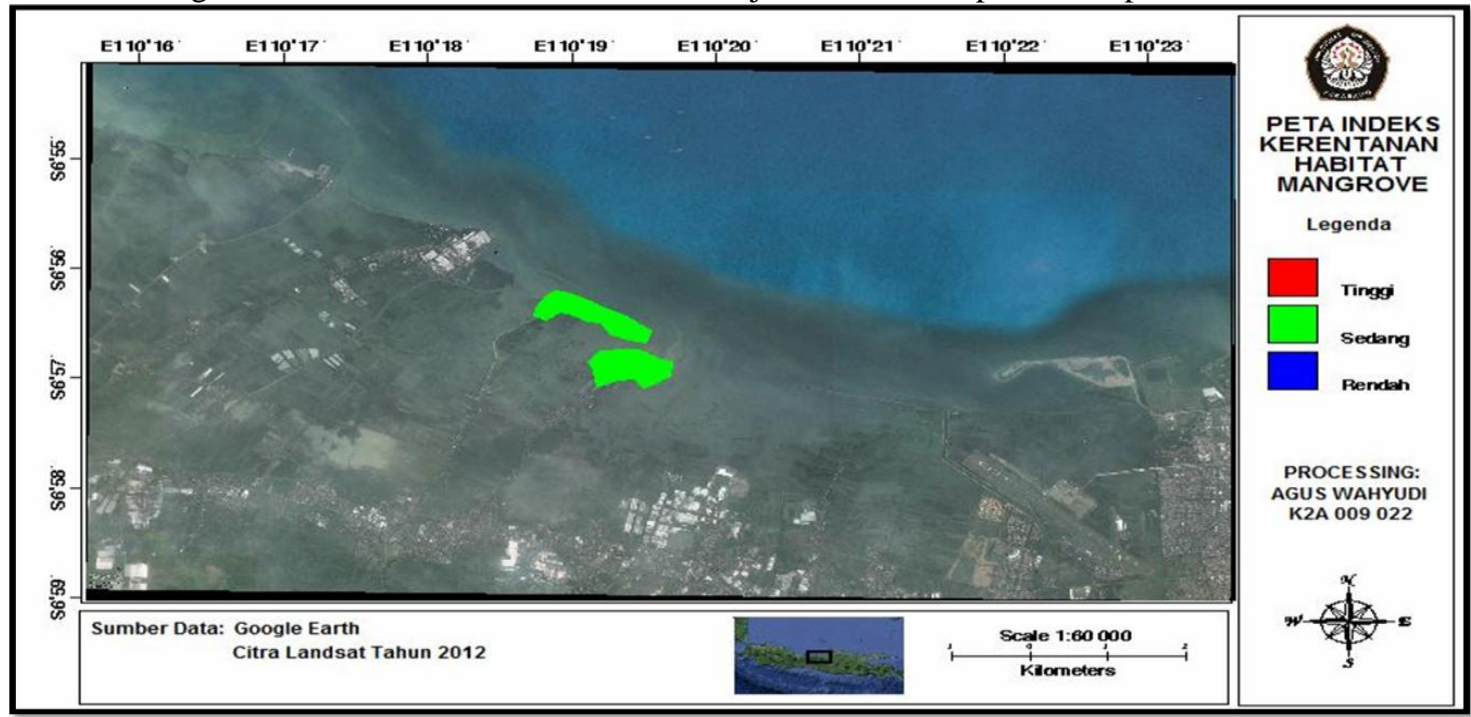

Gambar 4. Peta Indeks Kerentanan Habitat Mangrove Berdasarkan Variabel Jenis Substrat

\section{Penentuan Nilai Coastal Vulnerability Index}

Penentuan nilai Coastal Vulnerability Index dalam penelitian ini berdasarkan perhitungan variabel variabel yang mempengaruhi kerentanan habitat mangrove seperti frekuensi pasang surut, tinggi genangan maksimum, nilai salinitas, dan jenis substrat.

Berdasarkan hasil pengukuran dan pengamatan terhadap variabel frekuensi pasang surut (PS), tinggi genangan maksimum $(h)$, nilai salinitas (S), dan jenis substrat (JS) didapatkan nilai Coastal Vulnerability Index (CVI) yang tersaji dalam Tabel 5.

Tabel 5. Nilai CVI habitat mangrove

\begin{tabular}{cccccc}
\hline Zona & PS & $H$ & S & JS & CVI \\
\hline 1 & 3 & 3 & 1 & 2 & 2.12 \\
2 & 3 & 3 & 1 & 2 & 2.12 \\
\hline
\end{tabular}

Sumber: (Hasil Penelitian, 2013)

Gambar 5 menunjukkan bahwa tingkat kerentanan habitat mangrove di Kota Semarang berada di kategori tingkat kerentanan yang rendah karena nilai CVI yang didapat berada dalam kisaran $0,45-4,02$ berdasarkan klasifikasi indeks kerentanan habitat mangrove pada Tabel 6.

Tabel 6. Klasifikasi Indeks Kerentanan Habitat Mangrove

\begin{tabular}{cccc}
\hline NILAI CVI & $0.45-4.02$ & $4.03-8.04$ & $8.05-12.07$ \\
\hline KERENTANAN & Rendah & Sedang & Tinggi \\
\hline
\end{tabular}

Sumber: (Borruf, 2005) 


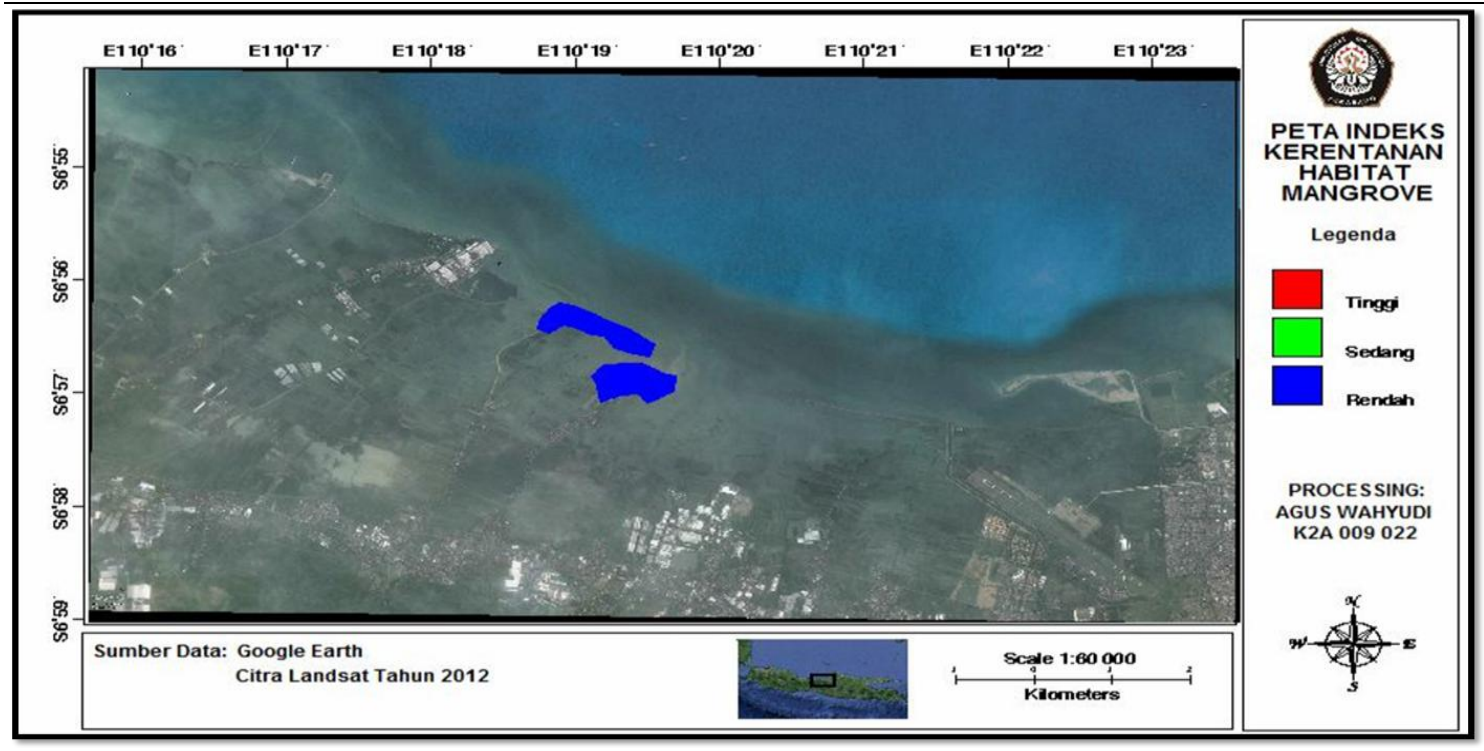

\section{Pembahasan}

Gambar 5. Peta Indeks Kerentanan Habitat Mangrove

\section{Nilai Indeks Kerentanan Habitat Mangrove}

Metode CVI ini merupakan metode yang baik digunakan untuk penilaian kerentanan di wilayah pesisir karena selain mudah dipahami dan dilakukan, metode CVI ini juga bisa diterapkan di setiap kondisi wilayah pesisir dan ketersediaan variabel dapat disesuikan dengan kondisi dan lokasi wilayah pesisir ataupun objek yang akan dikaji.

Variabel pasang surut memiliki pengaruh terhadap keberlangsungan pertumbuhan mangrove karena pasang surut merupakan faktor yang juga mempengaruhi ketersediaan air payau sehingga mempengaruhi kadar salinitas pada habitat mangrove, selain itu lama waktu penggenangan sangant mempengaruhi sistem perakaran pada mangrove seperti pada saat pasang akan mengurangi pasokan oksigen yg akan diserap oleh akar, sedangkan untuk seedling (anakan) akan kesulitan mendapatkan oksigen pada saat waktu penggenangan dan menganggu transfer nutrien dan fosfor masuk ke dalam habitat mangrove.

Pasang surut di Kota Semarang bersifat condong ke harian tunggal yang artinya bahwa pasang surut di Kota Semarang termasuk di lokasi penelitian mengalami pasang satu kali dan surut satu kali dalam satu harinya. Hal ini mengakibatkan kondisi habitat mangrove pada lokasi penelitan memiliki sifat kerentanan yang tinggi karena pada kondisi yang baik mangrove pada umumnya mengalami penggenangan 10-19 hari dalam setiap bulannya. Menurut Zaki et al, 2012 lama waktu penggenangan di daerah Mangunharjo terjadi setiap hari atau mangrove di daerah tersebut selalu tergenang selama 30 hari dalam setiap bulannya yang akan berdampak pada keberlangsungan hidup mangrove karena kondisi habitat mangroe yang baik itu terendam hanya selama 20 kali dalam satu bulannya.

Ketinggian maksimum air saat terjadinya pasang juga mempengaruhi keberlangsungan hidup mangrove karena tinggi perendaman akan berdampak pada kehidupan akar mangrove sebagai penyerap nutrien yang ada pada substrat sehingga ketinggian air pada saat perendaman air pasang juga harus diperhatikan. Hasil yang didapatkan pada pengolahan data pasang surut menghasilkan bahwa ketinggain air pada saat pasang yaitu $1,075 \mathrm{~m}$, hal ini menunjukkan bahwa habitat mangrove pada lokasi penelitian memiliki sifat kerentanan yang tinggi jika dilihat dari faktor tingginya perendaman saat pasang. Ketinggian maksimum air pasang yang ada di Mangunharjo dapat menganggu aktivitas pertumbuhan mangrove. Ketinggian air pasang di daerah Mangunharjo berkisar 0,5-0,7 kondisi tinggi perendaman untuk pertumbuhan mangrove berkisar pada 0,5 $1 \mathrm{~m}$ untuk setiap kali perendaman, sedangkan untuk kondisi baik pada habitat mangrove ketinggian genangan air pada saat pasang yaitu dibawah $0,5 \mathrm{~m}$ (Zaki et al, 2012).

Berdasarkan variabel salinitas nilai salinitas yang didapatkan saat pengukuran berkisar antara $29-30 \%$ maka habitat mangrove termasuk dalam kategori rendah kerentanannya karena mangrove bisa beradaptasi dengan baik pada kisaran salinitas $15-30 \%$ bahkan ada beberapa jenis mangrove yang mampu beradaptasi untuk kisaran nilai salinitas yang lebih rendah dari $15 \%$. Menurut Zaki et al, 2012 salinitas yang berkisar diantara $29-30 \%$, cukup baik mangrove di lokasi tersebut jenisnya berupa Avicennia dan Rhizopora yang mampu beradaptasi dengan baik untuk kondisi salinitas tersebut.

Pengaruh Salinitas pada kehidupan mangrove adalah pada propagul membantu dalam perkembangnnya. Propagul merupakan buah mangrove yang telah mengalami perkecambahan. Propagu terbagi dua yaitu vivipari dan kriptovivipari. Vivipari adalah biji yang telah berkecambah ketika masih melekat pada pohon induknya dan kecambah telah keluar dari buah, sedangkan kriptovivipari adalah adalah biji yang telah berkecambah, ketika masih melekat pada pohon induknya, tetapi masih tertutup oleh kulit, sedangkan untuk 
seedling (anakan,) membantu pada pertumbuhan terutama dalam mendapatkan makanan pada aktivitas fotosintesis.

Pada variabel jenis substrat didapatkan hasil uji laboratorium bahwa kandungan substrat pada lokasi penelitian didominasi $90 \%$ lebih oleh jenis pasir dan sisanya berupa lanau dan lempung. Berdasarkan kelas kategori indeks kerentanan habitat mangrove maka kondisi habitat mangrove berdasarkan jenis substrat termasuk ke dalam kategori sedang, karena pada dasarnya untuk kondisi habitat mangrove yang baik mangrove dapat tumbuh dengan baik pada kondisi substrat yang berlumpur. Jenis substrat pasir yang mendominasi habitat mangrove pada lokasi penelitian ini disebabkan karena kondisi geografis pada lokasi penelitan bersifat landai dan merupakan daerah pantai yang terbuka sehingga endapan substrat pasir banyak ditemukan pada habitat mangrove ini.

Substrat yang baik untuk kehidupan mangrove adalah substrat lanau karena substrat lanau memiliki ukuran butir substrat yang kecil dan halus sehingga pada penyerapan nutrien oleh akar dapat berlangsung dengan baik dan mudah. Hal inilah yang membuat banyak spesies mangrove yang ditemukan di substrat lanau seperti Rhizopora apiculata, Rhizopora stylosa, Rhizopora mucronata dan Sonneratia alba, sedangkan untuk substrat berpasir banyak ditemukan jenis Avicennia marina dan Rhizopra mucronata yang mendominasi jenis mangrove di wilayah tersebut (Kusmana, 1997).

Substrat yang baik untuk jenis mangrove di lokasi tersebut yaitu pasir berlanau karena susbtrat pasir dapat membantu akar mangrove dalam penyerapan nutrien. Substrat pasir berlanau banyak ditemukan di lokasi habitat mangrove yang mendekati pantai (Zaki et al, 2012).

Metode CVI menjadi metode yang sering digunakan dalam penilaian kerentanan wilayah pesisir karena metode CVI merupakan metode yang dapat diterapkan di suatu lokasi atau daerah pesisir yang memiliki keterbatasan faktor atau variabel data dan juga dapat diterapkan pada daerah yang memiki data yang banyak. Metode CVI banyak menerapkan konsep penggabungan dari beberapa variabel untuk mendapatkan nilai kerentanan dari suatu daerah pesisir atau objek yang akan dikaji.

Nilai indeks kerentanan habitat mangrove pada penelitian ini berdasarkan metode CVI didapatkan nilai indeksnya sebesar 2.12. Nilai indeks kerentanan ini dihasilkan dari penggabungan varaiabel - variabel seperti frekuensi lama waktu penggenangan, $h$ pasang surut maksimum, nilai salinitas, dan jenis substrat. Berdasarkan penggabungan dari variebel - variabel tersebut maka kerentanan habitat mangrove pada lokasi penelitian tersebut termasuk ke dalam kategori rendah. Hal ini mengacu pada klasifikasi nilai indeks kerentanan habitat mangrove.

Nilai indeks kerentanan pada setiap variabel yang dianggap mempengaruhi kerentanan pada habitat mangrove dapat dijadiakan acuan pengelolaan upaya memperabaiki kondisi habitat mangrove karena pada variabel pasang surut kondisi habitat mangrove termasuk kedalam kategori tinggi, sehingga peristiwa pasang surut pada daerah tersebut dapat membuat kondisi habitat mangrove pada daerah penelitian menjadi rusak selain pasang surut variabel lainnya seperti salinitas dan jenis substrat juga mempengaruhi kerentanan walaupun kisaran kerentanannya masih dalam kategori rendah dan sedang.

Nilai indeks kerentanan yang didapatkan ini bukan mencerminkan bahwa kondisi habitat mangrove pada lokasi penelitian termasuk dalam kondisi baik karena nilai kerentanannya terdapat pada kisaran kerentanan rendah, akan tetapi perlu adanya kajian secara menyeluruh terhadap faktor atau variabel yang dianggap mempengaruhi kerentanan habitat mangrove selain variabel -variabel pasang surut, nilai salinitas, dan jenis substrat sehingga didapatkan secara lebih menyeluruh mengenai kondisi habitat mangrove yang berada di lokasi penelitian.

\section{Kesimpulan}

Kesimpulan yang didapatkan dari penelitian ini adalah nilai Indeks Kerentanan Habitat Mangrove pada lokasi penelitian yaitu 2.12 maka kategori Indeks Kerentanan Habitat Mangrove pada lokasi penelitian termasuk kedalam kategori kerentanan rendah.

\section{Daftar Pustaka}

Boruff, 2005. Erosion Hazard Vulnerability of US Coastal Countries. Journal of Coastal Research. 21 (5). 932-942.

Chapman, V. J. 1976. Mangrove Vegetation. J. Cramer, Vaduz. Germany.

Dinas Kelautan dan Perikanan. 2012. Identifikasi Kerusakan dan Perencanaan Rehabilitasi Pantura Jawa Tengah. Kementerian Kelautan dan Perikanan Satuan Kerja Dinas Kelautan dan Perikanan Provinsi Jawa Tengah.

Fachrul, M. F. 2007. Metode Sampling Bioekologi. Bumi Aksara. Jakarta.

Foreman, M.G.G. 2004. Manual For Tidal Height Analysis and Prediction. Institut of Ocean Sciences.Sidney. B.C.

Giesen, Wim, M. Zieren dan L. Scholten. 2006. Mangrove Guidebook for Southeast asia. FAO and Wetlands Internasional. Thailand. 
Hartoko, A. 2002. Studi Pemetaan Wilayah dan Sumber Daya Pesisir Kabupaten Demak. Laporan Penelitian Bappeda Kabupaten Demak dan Fakultas Perikanan dan Ilmu Kelautan UNDIP. Laporan Penelitian.

Hartoko, A. dan M. Helmi. 2008. Development of Digital Multilayer Ecological Model for Padang Coastal Water (West Sumatra). Project Report. Fac of Fisheries and Marine Science.

Kathiresan, K. dan T. S. Thangam, 1990. A note on the effects of salinity and $p \mathrm{H}$ on growth of Rhizophora seedlings. The Indian Forester, Annamalai University.

Kementerian Kehutanan. 2012. Data dan Informasi Mangrove Sempadan Pantai. Direktorat Jenderal Bina Pengelolaan DAS dan Perhutanan Nasional. Jakarta.

Kusmana, C. 1997. Ekologi dan Sumberdaya Ekosistem Mangrove. Makalah Pelatihan Pengelolaan Hutan Mangrove Lestari Angkatan I PKSPL. Institut Pertanian Bogor, Bogor.

Messerschmidt, D. A. 1995. Rapid Appraisal for Cummunity Forestry. Methodology Series. International Institute for Environment and Development . UK-London.

Onrizal, 2008. Teknik Survey dan Analisis Data Sumberdaya Mangrove. Universitas Sumatera Utara. Medan.

Ramieri. E., A. Hartley, A. Barbanti, F. D. Santos, P. Laihonen, N. Marinova, dan M. Santini, Methods for Assessing Coastal Vulnerability to Climate Change. ETC CCA Background Paper. European Environment Agency, Copenhagen (DK) 8-9 June 2011.

USGS. 1999. National Assessment of Coastal Vulnerability to Sea-Level Rise: Preliminary Results for the U.S. Atlantic Coast. Unites States Geological Survey (USGS). http://pubs.usgs.gov/of/1999/of99593/pages/data. html. 9 Juli 2103

Zaki A. R, C. A. Suryono, R. Pribadi. 2012. Kajian Kondisi Lahan Mangrove di Desa Bedono, Kecamatan Sayung, Kabupaten Demak dan Kelurahan Mangunharjo, Kecamatan Tugu, Kota Semarang. Journal of Marine Research 1 (2). 88 - 97. Universitas Diponegoro. Semarang. 